\section{Military rank and AIDS proportionate mortality in the Brazilian Navy}

\author{
Hierarquia militar e mortalidade proporcional por \\ AIDS na Marinha do Brasil
}

\section{${ }^{1}$ Instituto de Ciências da Saúde, Universidade Federal da Bahia, Salvador, Brasil. 2 Instituto de Saúde Coletiva, Universidade Federal da Bahia, Salvador, Brasil. \\ Correspondence M. Silva \\ Programa Integrado em Saúde Ambiental e do Trabalhador, Instituto de Saúde Coletiva, Universidade Federal da Bahia. Rua Augusto Vianna s/n, 2 o andar, Salvador, $B A$ 40110-070, Brasil. marlenes@ufba.br}


macho behaviors associated with increased risk of unprotected or commercial sex ${ }^{8}$. There are also reports that military personnel are more likely to have AIDS or HIV infection in both developed and developing countries ${ }^{9}$, because they are engaged more frequently in promiscuous sexual behavior 9,10 and intravenous drug use 9 , both of which are known risk factors for HIV transmission.

In Brazil, HIV prevalence among seamen and petty officers (first class) was estimated as twice the overall rate for the Brazilian Navy 11. From 1985 through 1998, 673 HIV-positive cases were reported in the Navy, mostly among younger individuals 12 , but little is known about groups at increased risk. In this study, AIDS proportionate mortality is described in the Brazilian Navy from 1991 through 1995, according to socio-demographic and occupational groups and job titles.

\section{Methods}

This is a proportionate mortality study that includes all active, reserve, or retired Naval personnel who died from January 1, 1991, through December 31, 1995, and were residing in Brazil or abroad. The original project was intended to examine the associations between occupation and overall mortality in the Navy. Because AIDS cases were limited to 20 to 72 years of age, the study population was defined within this age range, so deaths at other ages were excluded. The database comes from the Military Personnel Division of the Brazilian Navy, while death information and job histories were obtained from the Social and Life Insurance Service of the Brazilian Navy, responsible for verifying relatives' compensation when a service member dies. The study population includes onshore and onboard Navy personnel and the inactive reserve corps. Withdrawal, desertion, and involuntary discharge are rare in this population. Because Navy recruitment of women is recent in Brazil and there were only a few female deaths recorded, this study includes only the male population.

Information about Naval military deaths is compiled from legal Brazilian death records and stored in the Navy Insurance System as death certificates. Agreement in terms of International Classification of Diseases - 9th Revision codes for the death records and death certificates was examined in a random sample of 106 subjects from the study population. An overall agreement of 89.6\% and a kappa index of 0.61 (95\%CI: 0.510.72 ) were estimated, thus demonstrating acceptable reliability in the available data. Information from occupational history files was compared, checking missing and homonymous data.
The study variables were age, marital status, calendar year of death, and place of residence according to State and region. The occupational variables were years served in the Navy, naval rank such as: high - sergeants and sub-officers, marine guards, lieutenants, captains, and admirals; and low - soldiers, seamen, and corporals or petty officers (first class). The occupational groups were defined based on job titles: combat/weapons - handling of submarine weapon artillery, missile technicians, minemen, gunner's mates, torpedomen's mate, and infantry; health care - physicians, dentists, nurses, pharmacists, psychologists, and x-ray operators; mechanical/ metalworking - machine and engine operators, aircraft maintenance operators, craft workers, metal workers, boiler operators, among others; communications/electro-electronics-internal naval communications, radar and sonar operators, electronics operators in general, aircraft technicians, electricians, radiomen; management - naval sciences graduates or Armed corps officers, hydrographers, managers and administrative support staff, musicians, chaplains, storage personnel; construction/repair - construction workers, crafts workers, carpenters, damage repair, engineers; services - cooks, janitors, barracks workers, barbers. Job titles comprising each occupational group were also evaluated separately. For each category, the referent group was all other occupational groups.

\section{Statistical analysis}

Age-standardized AIDS proportionate mortality was estimated using the direct method, with the overall study population as the standard. Measure of association was the proportionate mortality odds ratios (PMOR) 13 and statistical inference was based on Mantel-Haenszel confidence intervals for an alpha of 0.05. Unconditional logistic regression was also used to assess whether each occupational group was associated with AIDS proportionate mortality, separately, independently of confounding variables and taking effect modifier variables into consideration. Candidate confounders were age, marital status, and place of residence, and effect modification was examined for naval rank, years served in the Navy, and marital status. Modeling was based on backward elimination of terms from a saturated model containing all candidate variables. Confounding assessment was based on findings from previous studies 5,14 or when deletion of candidates from the saturated model led to changes greater than or equal to $20 \%$ in the main association. Effect modifiers were examined using maxi- 
mum likelihood ratio tests by considering an alpha of 0.05. Regression diagnosis was conducted using deviance analysis and colinearity checked with Pearson correlation, variance inflaction, and conditional index. Data entry and management were done with Epi Info 6.03 (Centers for Disease Control and Prevention, Atlanta, USA) and statistical analysis performed with SAS 8.1 (SAS Institute Inc., Cary, USA). Because these were administrative data, the study protocol was not submitted to the respective Institutional Review Board for examination of ethical issues. However, formal authorization was obtained to use the database.

\section{Results}

During the study period, 3,882 deaths were recorded in the Brazilian Navy, but 319 (8.2\%) death certificates could not be found, and 977 were out of the age range defined for the study population (20 to 72 years of age), leaving 2,586 deaths for analysis. AIDS cases were younger, mostly unmarried, and had lower socioeconomic status as compared to all other deaths. Unadjusted AIDS proportionate mortality $\left(\mathrm{PM}_{\text {unadjusted }}\right)$ was estimated at $4.83 \%$. From 1991 to 1995, AIDS proportionate mortality increased slightly, varying from $3.59 \%$ to $5.77 \%$ for all ages. However, the younger group (20 to 49 years) showed a much greater increase, from $9.92 \%$ to $22.22 \%$ (Figure 1). Age-adjusted AIDS proportionate mortality also increased during this time period in the two rank groups, but the increase was higher among lowranking military men (Figure 2).

Independently of age, the estimates show that unmarried low-ranking servicemen and those with fewer years of duty had a higher proportion of AIDS deaths than the comparison group (Table 1). Data in Table 2 show that AIDS proportionate mortality did not vary substantially across occupational groups, except for "secretarial" personnel, who had twice the AIDS proportionate mortality odds ratio $\left(\mathrm{PMOR}_{\text {unadjusted }}=2.29 ; 95 \% \mathrm{CI}\right.$ : 1.39-3.78) as compared to other occupations.

Based on logistic regression, naval rank was an effect modifier of the association between "management" occupations and AIDS proportionate mortality (likelihood ratio test, $\chi^{2}=5.89_{1 \mathrm{df}}$, $\mathrm{p}=0.02$ ); therefore, estimates are presented separately for each rank group. In the low-ranking group, the age-adjusted AIDS proportionate mortality odds ratio $\left(\mathrm{PMOR}_{\text {age-adjusted }}\right)$ corresponding to "management" was 2.45 (95\%CI: 1.27-4.71), higher than the estimate for the higher-ranking group $\left(\mathrm{PMOR}_{\text {age-adjusted }}=0.73,95 \% \mathrm{CI}\right.$ : 0.36-1.47), a statistically significant difference. However, a negative association with "combat/weapons" was found in the low-rank group ( $\mathrm{PMOR}_{\text {age-adjust- }}$ ed $=0.42,95 \% \mathrm{CI}$ : $0.22-0.81$ ), which is statistically different from the PMOR age-adjusted $=1.01$ (95\%CI: $0.49-2.05)$ estimated in the high-ranking group. Limited to the low-rank group, AIDS proportionate mortality was higher among "secretarial" $\left(\mathrm{PMOR}_{\text {age-adjusted }}=2.49,95 \% \mathrm{CI}: 1.22-5.08\right)$ and "janitorial" personnel (PMOR age-adjusted $=2.61$, 95\%CI: 1.10-6.16) as compared to all other occupations (Table 3 ).

\section{Discussion}

The findings from this study suggest that in the Brazilian Navy, males have a high AIDS proportionate mortality that increased from 1991 to 1995 , particularly in the younger group and among low-rank servicemen. AIDS proportionate mortality was also more common in the lowranking group as compared to the higher ranks during the overall study period, and this difference increased from 1992 to 1995. Secretarial personnel, a sub-group of the "management" category, had an elevated proportion of AIDS-related deaths as compared to other occupational groups, and this difference changed according to military rank. Occupations were associated with AIDS proportionate mortality only among low-ranking Navy personnel, which include soldiers, seamen, and petty officers. In this lowranking group, the proportion of AIDS deaths in the "management" stratum, particularly among secretarial personnel, was higher than in other occupational groups. Janitorial personnel also had increased AIDS proportionate mortality as compared to other occupations in the low-ranking group. However, "combat/weapons" occupations showed lower AIDS proportionate mortality, especially among the lower ranks as compared to the referent group.

AIDS proportionate mortality in the Brazilian Navy was higher than estimated for the overall male population $(2 \%)$ during the same time period in Brazil 3. This is consistent with research findings showing increased prevalence of HIV infection in the Armed Forces of several countries 9,10 , including Brazil itself 11 , but no data on AIDS mortality were available for the Navy. Usually, on-duty tasks require long periods of time away from home, living in remote places and frequent travel, which could account for unsafe sexual behavior 12. This is evident in the increased incidence of sexually transmitted diseases among servicemen 9,10. Careless sexual practices in this population can be even worse considering the so-called "military barracks culture", where ma- 
Figure 1

AIDS proportionate mortality in the Brazilian Navy according to calendar year and age.

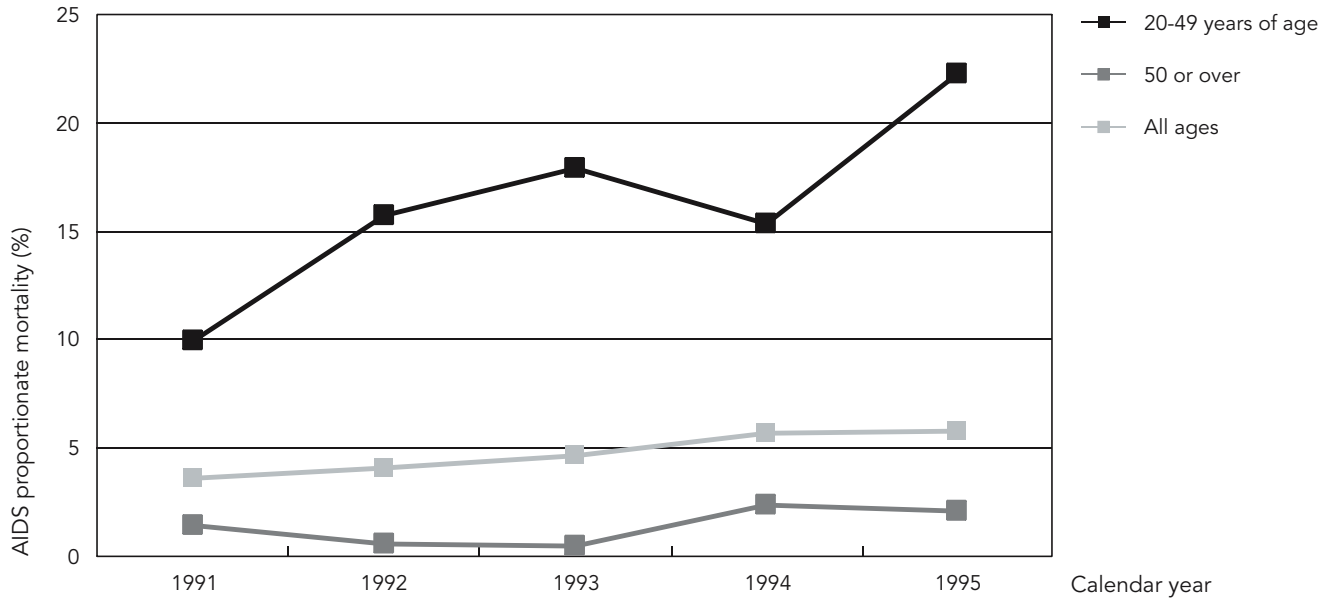

Figure 2

Age-adjusted AIDS proportionate mortality in the Brazilian Navy according to calendar year and naval rank.

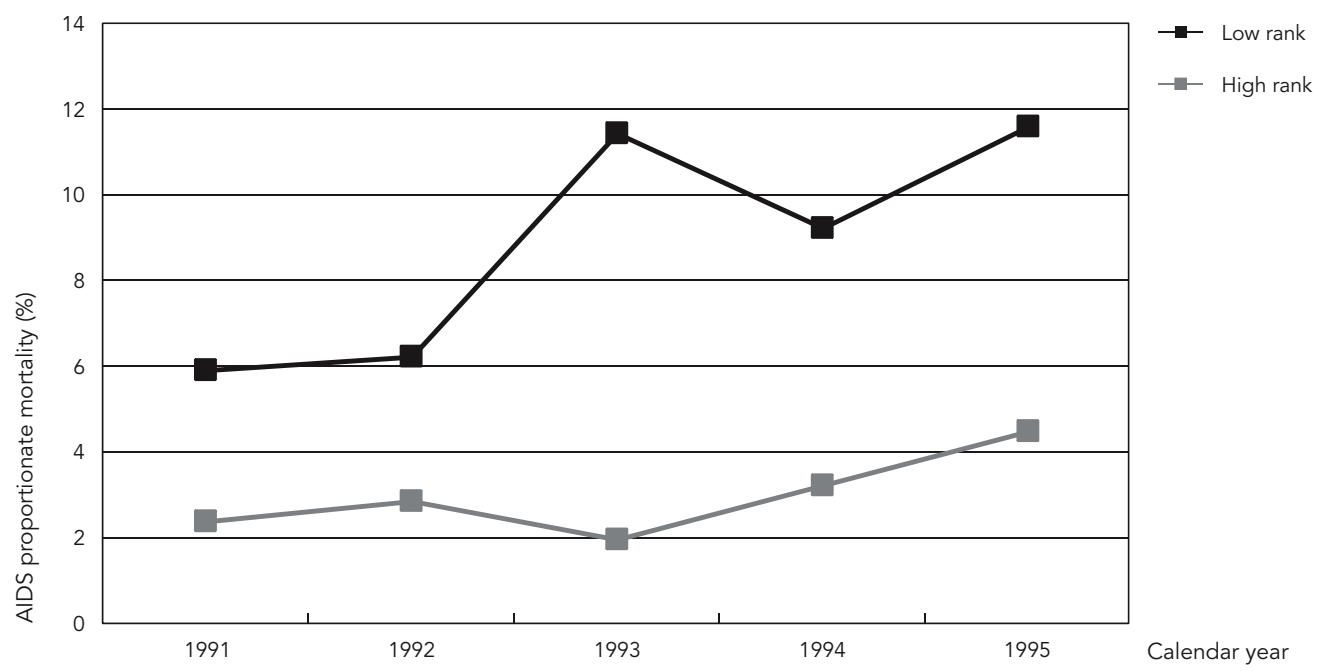


Unadjusted and age-adjusted AIDS proportionate mortality according to socio-demographic and occupational variables in the Brazilian Navy, 1991-1995.

\begin{tabular}{|c|c|c|c|c|}
\hline Variables & $\begin{array}{l}\text { All deaths } \\
(\mathrm{N}=2,586)\end{array}$ & $\begin{array}{c}\text { AIDS } \\
\text { deaths } \\
(n=125)\end{array}$ & $\begin{array}{c}\text { AIDS } \\
\text { proportionate } \\
\text { mortality }(4.83 \%)\end{array}$ & $\begin{array}{c}\text { Age-adjusted } \\
\text { proportionate } \\
\text { mortality (4.80\%) }\end{array}$ \\
\hline \multicolumn{5}{|c|}{ Age in years $(p<0.001)$} \\
\hline $50-72$ & 29 & 1,960 & 0.48 & - \\
\hline $20-49$ & 96 & 501 & 19.16 & - \\
\hline \multicolumn{5}{|c|}{ Marital status $(p<0.001)$} \\
\hline Married & 2,021 & 51 & 2.52 & 3.17 \\
\hline Unmarried & 565 & 74 & 13.10 & 10.10 \\
\hline \multicolumn{5}{|c|}{ Region of residence } \\
\hline Southeast & 1,836 & 88 & 4.79 & 4.64 \\
\hline Northeast & 499 & 23 & 4.60 & 5.68 \\
\hline North & 80 & 6 & 7.50 & 5.10 \\
\hline Central-west & 69 & 4 & 5.80 & 4.43 \\
\hline South & 88 & 4 & 4.55 & 7.14 \\
\hline \multicolumn{5}{|c|}{ Naval rank $(p<0.001)$ * } \\
\hline High & 1,791 & 54 & 3.02 & 3.85 \\
\hline Low & 795 & 71 & 8.93 & 5.30 \\
\hline \multicolumn{5}{|c|}{ Service time in years } \\
\hline $0-10$ & 452 & 40 & 8.85 & 3.96 \\
\hline $11-25$ & 1,124 & 55 & 4.89 & 4.29 \\
\hline $26-53$ & 1,010 & 30 & 2.97 & 3.94 \\
\hline
\end{tabular}

* Naval rank: high = sergeants and officers; low = soldiers, seamen, and petty officers.

cho behavior is praised and reinforced by peer pressure, and feelings of power and invincibility may be an obstacle to preventive sexual behavior 12,15. Intravenous illicit drug use has been examined among conscripts, but self-reporting and urine tests have shown reduced prevalence 10 .

Like the upward time trend observed in the Navy, AIDS proportionate mortality was increasing among the Brazilian civilian population 3 before highly active antiretroviral therapy (HAART) became available free of cost in public health services for all eligible individuals in 1996. The Brazilian trend also reflects the worldwide epidemic pattern during the same time period. The increased AIDS proportionate mortality among young servicemen is also consistent with findings in the general population, showing AIDS as a disease of youth ${ }^{1}$ before the more recent trends showing middle-aged and elderly individuals at increased risk of HIV infection. The relative excess of AIDS deaths among single military men as compared to married servicemen in this study is suggestive of homosexual patterns.

In this study, the social inequities in AIDS proportionate mortality in the Brazilian Navy are evident in the inverse association with Naval rank, reproducing the pattern in the general population, described as impoverishment of the AIDS epidemic 14 . Military rank represents social class differences but also strong hierarchical relations of power and dominance 15, typical of military organizations, which may influence the nature and direction of sexual negotiation. It may be of particular interest in same-sex relations, heavily discriminated against and stigmatized in the military setting. This prejudice can be intensified among less-educated, low-ranking military men, thus explaining their increased AIDS proportionate mortality. It is also plausible that other risk factors for AIDS-related deaths described in association with low socioeconomic status in the general population, such as promiscuous behavior, unsafe sex, and low sexual negotiating power 16 , may similarly occur in a low-ranking military setting.

It is unclear why the managerial occupational group and those with secretarial or janitorial positions showed an increased proportion of AIDSrelated deaths as compared to other occupations in the Navy. Only a few studies have focused on occupational AIDS patterns 6,14,17, and research with military populations did not address spe- 
AIDS proportionate mortality and proportionate mortality odds ratio for the association between occupation and AIDS death in the Brazilian Navy, 1991-1995.

\begin{tabular}{|c|c|c|c|c|}
\hline $\begin{array}{l}\text { Occupational } \\
\text { groups/Job titles }\end{array}$ & $\begin{array}{l}\text { All deaths } \\
(N=2,586)\end{array}$ & $\begin{array}{l}\text { AIDS deaths } \\
\quad(n=125)\end{array}$ & $\begin{array}{c}\text { AIDS } \\
\text { proportionate } \\
\text { mortality (4.83\%) }\end{array}$ & $\begin{array}{c}\text { PMOR } \\
(95 \% \mathrm{Cl}) \text { * }\end{array}$ \\
\hline Referent ** & - & - & - & 1.00 \\
\hline Management & 426 & 27 & 6.34 & $1.42(0.92-2.21)$ \\
\hline Secretarial & 209 & 20 & 9.57 & $2.29(1.39-3.78)$ \\
\hline Musicians & 60 & 3 & 5.00 & $1.04(0.32-3.36)$ \\
\hline Other & 107 & 4 & 3.74 & $0.76(0.27-2.09)$ \\
\hline Combat/Weapons & 544 & 23 & 4.23 & $0.84(0.53-1.33)$ \\
\hline Infantry & 329 & 17 & 5.17 & $1.08(0.64-1.83)$ \\
\hline Artillery & 131 & 3 & 2.29 & $0.45(0.14-1.43)$ \\
\hline Weapons & 74 & 3 & 4.05 & $0.83(0.26-2.67)$ \\
\hline Mechanical/Metalworking & 468 & 21 & 4.49 & $0.91(0.56-1.47)$ \\
\hline Mechanics and motors & 348 & 15 & 4.31 & $0.87(0.50-1.51)$ \\
\hline Metallurgy & 41 & 2 & 4.88 & $1.01(0.24-4.23)$ \\
\hline Other & 77 & 4 & 5.19 & $1.08(0.39-3.01)$ \\
\hline Services & 284 & 15 & 5.28 & $1.11(0.64-1.93)$ \\
\hline Cooks & 71 & 2 & 2.82 & $0.56(0.14-2.33)$ \\
\hline Janitorial $(p<0.10)$ & 160 & 12 & 7.50 & $1.66(0.89-3.08)$ \\
\hline Barbers & 31 & 1 & 3.23 & $0.65(0.09-4.83)$ \\
\hline Communications/Electro-electronic & 407 & 18 & 4.42 & $0.90(0.54-1.49)$ \\
\hline Electricians & 109 & 4 & 3.67 & $0.74(0.27-2.05)$ \\
\hline Electronics & 33 & 2 & 6.10 & $1.27(0.30-5.39)$ \\
\hline Sign operators & 71 & 6 & 8.45 & $1.86(0.79-4.38)$ \\
\hline Communications & 131 & 5 & 0.58 & $0.77(0.31-1.92)$ \\
\hline Radar operators & 23 & 1 & 4.35 & $0.89(0.12-6.69)$ \\
\hline Construction/Repair & 366 & 15 & 4.10 & $0.82(0.47-1.42)$ \\
\hline Deck operations & 307 & 10 & 3.26 & $0.63(0.33-1.22)$ \\
\hline Other $(p<0.10)$ & 48 & 5 & 10.42 & $2.34(0.91-6.02)$ \\
\hline Health care & 91 & 6 & 6.59 & $1.41(0.60-3.29)$ \\
\hline Nurses & 51 & 3 & 5.88 & $1.24(0.38-4.03)$ \\
\hline Physicians & 25 & 2 & 8.00 & $1.72(0.40-7.39)$ \\
\hline Dentists & 8 & 1 & 12.50 & $2.83(0.35-23.16)$ \\
\hline
\end{tabular}

PMOR = proportionate mortality odds ratio

* 95\% confidence interval using Mantel-Haenszel method;

** Referent: all other occupations.

cific occupations 9,10,11,12,15. Noticeable, however, is the interaction with low rank, suggestive of an important role of hierarchy in sexual behavior in military institutions that needs to be addressed in future studies. Regarding occupation, a Brazilian study 17 reported increased cumulative AIDS incidence among personal care workers, social scientists, writers, journalists, physicians, dentists, chemists, pharmacists, physicists, teachers, artists, sales personnel, and workers in port services and maritime and river transport. Greater risk of HIV infection has been observed among workers exposed to blood, body fluids, and infected materials, such as surgeons 6 , laboratory workers 6,17 , and nurses 6 , common occupations in military settings. However, our results do not show evidence of increased proportionate mortality in such jobs.

One major limitation of this study was the secondary nature of the data source. AIDS death recording could be underestimated due to AIDSrelated stigma, which may occur more frequently among those with higher ranks, leading to relatively increased estimates in the low-ranking group. The study's results are also limited by the small number of cases and the lack of work-related sexual or drug use behavior, recognized as major risk factors for HIV transmission. Reserve corps servicemen may be engaged in other occupations, but this information was not available for this analysis. The proportionate mortality odds ratio should be affected by the death pat- 
Age-adjusted AIDS proportionate mortality odds ratios for the association with occupational groups/job titles according to naval rank.

\begin{tabular}{|c|c|c|}
\hline \multirow{3}{*}{$\begin{array}{l}\text { Occupational } \\
\text { groups/Job titles }\end{array}$} & \multicolumn{2}{|c|}{ Naval rank * } \\
\hline & $\operatorname{Low}(n=795)$ & High $(n=1,791)$ \\
\hline & $\mathrm{PMOR}_{\text {adjusted }}(95 \% \mathrm{Cl})$ ** & PMOR $_{\text {adjusted }}(95 \% \mathrm{Cl})$ ** \\
\hline Referent $* \star \star$ & 1.00 & 1.00 \\
\hline Management & $2.45(1.27-4.71)$ & $0.73(0.36-1.47)$ \\
\hline Secretarial & $2.49(1.22-5.08)$ & $1.52(0.66-3.51)$ \\
\hline Musicians & $3.03(0.58-15.67)$ & $0.60(0.08-4.59)$ \\
\hline Other & - & $0.58(0.17-1.97)$ \\
\hline Combat/Weapons & $0.42(0.22-0.81)$ & $1.01(0.49-2.05)$ \\
\hline Infantry & $0.53(0.27-1.04)$ & $0.81(0.31-2.13)$ \\
\hline Artillery & $0.60(0.08-4.66)$ & $0.82(0.19-3.49)$ \\
\hline Weapons & - & $1.97(0.58-6.63)$ \\
\hline Mechanical/Metalworking & $0.91(0.45-1.81)$ & $0.89(0.42-1.87)$ \\
\hline Mechanics and motors & $1.04(0.48-2.27)$ & $0.83(0.35-2.00)$ \\
\hline Metallurgy & - & $1.63(0.36-7.30)$ \\
\hline Other & $0.86(0.23-3.22)$ & $0.62(0.08-4.76)$ \\
\hline Services & $1.11(0.53-2.32)$ & $1.80(0.69-4.72)$ \\
\hline Cooks & $0.38(0.05-2.89)$ & $2.56(0.87-7.53)$ \\
\hline Janitorial & $2.61(1.10-6.16)$ & $2.14(0.70-6.59)$ \\
\hline Barbers & $1.69(0.20-14.17)$ & - \\
\hline Communications/Electro-electronic & $1.19(0.55-2.58)$ & $0.97(0.46-2.04)$ \\
\hline Electricians & $1.99(0.54-7.35)$ & $0.48(0.06-3.56)$ \\
\hline Electronics & $1.57(0.15-16.82)$ & $0.77(0.10-5.93)$ \\
\hline Sign operators & $3.03(0.75-12.17)$ & $2.01(0.58-6.98)$ \\
\hline Communications & $0.30(0.04-2.35)$ & $1.67(0.58-4.83)$ \\
\hline Radar operators & $4.72(0.31-72.75)$ & - \\
\hline Construction/Repair & $0.99(0.44-2.20)$ & $1.41(0.61-3.24)$ \\
\hline Deck operators & $0.82(0.31-2.18)$ & $1.21(0.46-3.17)$ \\
\hline Other & $1.78(0.44-7.23)$ & $2.52(0.56-11.33)$ \\
\hline Health care & $2.71(0.70-10.44)$ & $0.99(0.29-3.42)$ \\
\hline Nurses & $2.71(0.70-10.44)$ & - \\
\hline Physicians & - & $1.80(0.38-8.57)$ \\
\hline Dentists & - & $4.81(0.46-49.92)$ \\
\hline
\end{tabular}

$\mathrm{PMOR}_{\text {adjusted }}=$ adjusted proportionate mortality odds ratio

* Naval rank: low = soldiers, seamen, and petty officers; high = sergeants and officers;

** $95 \%$ confidence interval using Wald test;

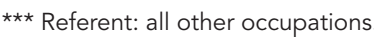

tern in the population and influenced by competing risks for each cause of death. Nonetheless, the age adjustment enabled better comparability with the referent group. The use of other deaths as the referent group has been questioned 13, but it can reduce potential bias due to differential quality of information and access to diagnostic resources. The healthy worker effect 13 was probably reduced in this study because deaths of all enlisted men were considered. Occupational changes following diagnosis were not plausible, since AIDS cases were withdrawn from duty immediately after diagnosis.
This study adds to the knowledge that there exists an excess of AIDS deaths among young low-ranking Brazilian Navy servicemen when secretarial/accounting or janitorial personnel are considered. It is plausible that power relations may affect sexual negotiation in military institutions, which highlights the need to conduct research aimed at a better understanding of the underlying factors for HIV transmission in this work environment, such as gender and education and its relations with the military hierarchy, a sensitive issue that needs to be addressed in further studies. 


\section{Resumo}

Este estudo descreve a mortalidade proporcional por AIDS associada aos fatores ocupacionais na Marinha do Brasil. Inclui 2.586 certidões de óbitos de militares entre 20 e 72 anos, ocorridos em 1991-1995. Os dados de certidões de óbitos e história ocupacional foram obtidos nos arquivos do Serviço de Inativos e Pensionistas da Marinha. Utiliza-se como medida de associação odds ratio de mortalidade proporcional obtida por regressão logística não condicional. Estimou-se uma mortalidade proporcional por AIDS de 4,8\% ( $n=$ 125) que aumentou no periodo, particularmente, entre os menores de 50 anos ou de nível hierárquico baixo. Nesta categoria, encontrou-se excesso relativo na mortalidade proporcional por AIDS nos grupos ocupacionais de "Administração" (odds ratio de mortalidade proporcional, ORMP ${ }_{\text {ajustada }}=2,45$; IC95\%: 1,27-4,71), "Secretaria" (ORMP ${ }_{\text {ajustada }}=2,49$; IC95\%: 1,22-5,08), e "Taifeiros" (ORMP ${ }_{\text {ajustada }}=2,61$; IC95\%: 1,10-6, 16), comparados às demais ocupações. A mortalidade proporcional por AIDS esteve aumentada entre militares do sexo masculino, sendo elevada em algumas ocupações no nível hierárquico baixo. Todavia, distribuição de poder, questões de gênero e nível sócio-econômico necessitam de melhor investigação com desenhos apropriados.

Síndrome de Imunodeficiência Adquirida; Militares; Mortalidade

\section{Contributors}

All the authors contributed to the preparation of this article. M. Silva conducted the data collection, analysis, and interpretation and drafted the article. V. Santana collaborated in the analysis and interpretation, scientific design, and critical analysis of the manuscript, and I. Dourado conducted the critical review and analysis of the manuscript.

\section{Acknowledgements}

This research was supported by the Social and Life Insurance Service of the Brazilian Navy $1^{\text {st }}$ Naval District, which made available all the data from the death records and occupational history of the servicemen.

Funding sources: Conselho Nacional de Desenvolvimento Científico e Tecnológico (CNPq) Ph.D. grant no. 141732/01-6 and National Institutes of Health/Fogarty Foundation (Grant no. 1043 TW00827-02), technical cooperation between the University of North Carolina at Chapel Hill, USA, and the Instituto de Saúde Coletiva, Universidade Federal da Bahia, Brazil.

\section{References}

1. Brito AM, Castilho EA, Szwarcwald CL. AIDS e infecção pelo HIV no Brasil: uma epidemia multifacetada. Rev Soc Bras Med Trop 2001; 34:207-17.

2. Gotlieb SLD, Castilho EA, Buchalla CM. O impacto da AIDS na esperança de vida, Brasil, 2000. Bol Epidemiol AIDS 2002; XVI:17-23.

3. Lemos KRV, Valente JG. Mortalidade por AIDS no Estado do Rio de Janeiro - 1991 a 1995. Cad Saúde Pública 2001; 17:957-68.

4. Ministério da Saúde. Mortalidade por AIDS no Brasil - atualização até 1997. Bol Epidemiol AIDS 1999; I:3-9.

5. Farias N, Cardoso MRA. Mortalidade por Aids e indicadores sociais no Município de São Paulo, 1994 a 2002. Rev Saúde Pública 2005; 39:198-205.

6. Kadla S, Malik GM. Risk of HIV infection in the health care setting. JK Pract 1997; 4:41-3.

7. Guerriero I, Ayres JRCM, Hearst N. Masculinidade e vulnerabilidade ao HIV de homens heterossexuais, São Paulo, SP. Rev Saúde Pública 2002; 36: 50-60.

8. Villarinho L, Bezerra I, Lacerda R, Latorre MRDO, Paiva V, Stall R, et al. Caminhoneiros de rota curta e sua vulnerabilidade ao HIV, Santos, SP. Rev Saúde Pública 2002; 36 (4 Suppl):61-7.

9. Miller N, Yeager R. By virtue of their occupation, soldiers and sailors are at greater risk. AIDS Anal Afr 1995; 5:8-9.

10. Nelson KE, Celentano DD, Eiumtrakol S, Hoover DR, Beyrer C, Suprasert S, et al. Changes in sexual behavior and a decline in HIV infection among young men in Thailand. N Engl J Med 1996; 335:297-303

11. Pinho DA, Pires PAA, Velloso LFN, Costa AC, As sumpção SMAM. Inquérito epidemiológico primário sobre SIDA em exames periciais na Marinha do Brasil. Arq Bras Med Naval 1992; 59:7-16.

12. Esher AFSC. AIDS na Marinha: vivendo o fim de uma carreira [Dissertação de Mestrado]. Rio de Janeiro: Escola Nacional de Saúde Pública, Fundação Oswaldo Cruz; 1999.

13. Rothman K, Greenland S. Modern epidemiology. 2nd Ed. Philadelphia: Lippincott-Raven; 1998.

14. Fonseca MGP, Travassos C, Bastos FI, Silva NV, Szwarcwald CL. Social distribution of AIDS in Brazil, according to labor market participation, occupation and socioeconomic status of cases from 1987 to 1998. Cad Saúde Pública 2003; 19:1351-63.

15. Costa EO, Germano RM. Asymmetrical relationships: sexuality, health, and power in the military. Rev Bras Enfermagem 2004; 57:48-52.

16. Parker R, Camargo Jr. KR. Pobreza e HIV/AIDS: aspectos antropológicos e sociológicos. Cad Saúde Pública 2000; 16 Suppl 1:89-102.

17. Cassano C, Frias LAM, Valente JG. Classificação por ocupação dos casos de AIDS no Brasil - 1995. Cad Saúde Pública 2000; 16 Suppl 1:53-64.

Submitted on 30/May/2005

Final version resubmitted on 23/Feb/2006

Approved on 10/Mar/2006 